\title{
Growth of Bacteria on Roots of Grasses: Influence of Mineral Nutrient Supply and Interactions between Species
}

\author{
By SHEILA M. TURNER $\dagger$ AND E. I. NEWMAN* \\ Botany Department, University of Bristol, Bristol BS8 1UG, UK
}

(Received 19 September 1983; revised 26 October 1983)

\begin{abstract}
Grass plants were grown axenically in sand and were then inoculated with either one bacterial species or a mixture of two species. Numbers of bacteria on the root surface were subsequently determined by dilution plating. When six bacterial species were inoculated on to separate Lolium perenne plants, the species with the smallest individual cells produced greatest numbers per $\mathrm{mg}$ root after $15 \mathrm{~d}$. When Serratia marcescens was inoculated on to three grass species, $L$. perenne, Holcus lanatus and Deschampsia flexuosa, there was no significant difference between the grasses in the number of bacteria per $\mathrm{mg}$ of root which subsequently developed. Serratia marcescens and a Flavobacterium sp. were inoculated, separately or together, on to L. perenne, grown either with a complete nutrient solution or one deficient in either nitrogen or phosphorus. The Flavobacterium sp. increased more slowly than $S$. marcescens, a difference enhanced when they were on the same plant. Decreased nitrogen supply, although it reduced plant growth, had no significant effect on bacterial numbers, whereas phosphorus deficiency increased the numbers of both bacterial species.
\end{abstract}

\section{INTRODUCTION}

The population density of a bacterial species in the rhizosphere could be influenced by $(a)$ physical and chemical conditions in the soil, $(b)$ the amount and nature of organic materials liberated by the root, $(c)$ interactions with other micro-organisms and $(d)$ predatory microfauna. To understand the factors controlling the rhizosphere microbial population is therefore very difficult, and it can be helpful to study a simplified model system in which some of these factors are excluded and others controlled. Here we describe experiments in which grass plants were established axenically in sand culture and then inoculated with one or two bacterial species, whose growth on the root surface was subsequently followed. A similar technique has been used by Bennett \& Lynch (1981) to study bacterial growth in the rhizosphere of cereals. Our experiments form part of a study of the effects of nitrogen and phosphorus supply on the microbial population of root surfaces of Lolium perenne, but they also provide information on the rate of colonization by motile and non-motile bacteria, on the time-course of competition between two bacterial species and on the growth of one bacterial species on three different grass species.

\section{METHODS}

General techniques. The plants were grown in sand in glass tubes $4.5 \mathrm{~cm}$ in diameter $\times 26 \mathrm{~cm}$ tall. The acid-washed sand was thoroughly cleaned by autoclaving three times with frequent rinsing between each. To obtain a wellaerated environment for the roots, the cleaned sand was oven-dried and then $160 \mathrm{~g}$ sand was mixed with only $20 \mathrm{ml}$ nutrient solution and placed in the tube. The 'complete' nutrient solution contained $\mathrm{KNO}_{3}, 5 \mathrm{mM} ; \mathrm{Ca}\left(\mathrm{NO}_{3}\right)_{2}$, $5 \mathrm{~mm} ; \mathrm{NaH}_{2} \mathrm{PO}_{4}, 6.5 \mathrm{mM} ; \mathrm{MgSO}_{4}, 2 \mathrm{mM} ; \mathrm{FeSO}_{4}, 0.37 \mathrm{mM}$; and micronutrients following the recipe of Arnon (1938) given by Hewitt (1966). The mouth of each tube was plugged with cotton wool and the tubes were autoclaved.

$†$ Present address: Department of Biochemistry, South Parks Road, Oxford OX1 3QU, UK. 


\section{Table 1. Details of the four experiments}

\begin{tabular}{|c|c|c|c|c|}
\hline & Expt 1 & Expt 2 & Expt 3 & Expt 4 \\
\hline Grass species & L. perenne & $\begin{array}{l}\text { L. perenne } \\
H . \text { lanatus } \\
\text { D. flexuosa }\end{array}$ & L. perenne & L. perenne \\
\hline Bacterium species & All 6 & S. marcescens & $\begin{array}{l}\text { S. marcescens } \\
\text { Flavobacterium sp. A }\end{array}$ & $\begin{array}{l}\text { S. marcescens } \\
\text { Flavobacterium sp. A }\end{array}$ \\
\hline Nutrient solutions & Complete & Complete & $\begin{array}{l}\text { Complete, } \\
\text { Low-N }\end{array}$ & $\begin{array}{l}\text { Complete, } \\
\text { Low-P }\end{array}$ \\
\hline $\begin{array}{l}\text { Age of plants when inoculated with } \\
\text { bacteria (d after planting date) }\end{array}$ & 21 & $42,16,14^{*}$ & 21 & 21 \\
\hline Time of harvests ( $d$ after inoculation) & 10,15 & 14,20 & $2,4,7,10,14$ & $2,4,7,10,14$ \\
\hline No. of replicate tubes per treatment & 2 & 6 & 3 & 3 \\
\hline
\end{tabular}

* For D. flexuosa, L. perenne and $\boldsymbol{H}$. lanatus, respectively.

The grass species were Lolium perenne L. cv. S23, Holcus lanatus L. and Deschampsia flexuosa (L.) Trin. Seeds were sterilized by removing the lemma and palea and placing the seeds in a solution of $2.5 \%(\mathrm{w} / \mathrm{v}) \mathrm{AgNO}_{3}+1 \%$ (wiv) Brij 35 for $5 \mathrm{~min}$ ( $3 \mathrm{~min}$ for $D$. flexuosa) under reduced pressure. Sterile $\mathrm{NaCl}$ solution was then added to precipitate the Ag: the seeds were transferred to $95 \%(\mathrm{v} / \mathrm{v})$ ethanol for $1 \mathrm{~min}$, washed in three changes of sterile distilled water and germinated on malt extract agar. Young healthy seedlings showing no contamination were planted aseptically into the sand, one per tube. The tubes were placed in a growth cabinet at $17^{\circ} \mathrm{C}$ constant, approximately $70 \%$ relative humidity, $16 \mathrm{~h}$ light period with photosynthetically active radiation approximately $250 \mu \mathrm{E} \mathrm{m}^{-2} \mathrm{~s}^{-1}$. As the relative humidity was kept high, and because of the cotton wool bung, water loss from the tubes was very slow and no water was added during the experiments. By keeping the temperature constant condensation on the sides of the tubes was minimized.

The six pure cultures of bacteria used for inoculation of the plants were originally isolated from the root surfaces of $L$. perenne plants growing in soil collected from a permanent pasture. One was identified as Serratia marcescens and four as Flavobacterium spp. The sixth, a non-motile Gram-variable pleomorphic rod, could not be identified. The $S$. marcescens and the Flacobacterium spp. were tested for their ability to metabolize sugars: all could use glucose, sucrose and lactose, but they varied in their use of other sugars. All six organisms could use $\mathrm{NH}_{4} \mathrm{NO}_{3}$ as the sole nitrogen source. None of them could degrade cellulose or pectin. Serratia marcescens was the only motile species and the only facultative anaerobe. The bacteria were grown on 1/10-strength tryptic soy agar. From this culture a suspension containing about 500 bacteria $\mathrm{ml}^{-1}$ was prepared in 1/4-strength Ringer's solution and $1 \mathrm{ml}$ was pipetted on to the surface of the sand near the base of each plant.

At harvest the roots were carefully washed free of sand in sterile distilled water. They were shaken for $15 \mathrm{~min}$ with glass beads in sterile distilled water, and the number of bacteria in the resulting suspension was determined by dilution plating on to $1 / 10$-strength tryptic soy agar. The plates were incubated at $25^{\circ} \mathrm{C}$ and counts were made after about $4 \mathrm{~d}$. The roots and shoots were dried in an oven and weighed. Later the shoots were digested in conc. $\mathrm{H}_{2} \mathrm{SO}_{4}$, and their nitrogen and phosphorus contents were determined colorimetrically on an automatic analyser.

Individual experiments. Table 1 shows details of the experiments.

Expt $I$ was a preliminary experiment in which growth of all six bacterial species on $L$. perenne was measured. Cell length and width were measured on about 100 bacteria of each species grown on 1/10-strength tryptic soy agar for $7 \mathrm{~d}$. The mean cell volume was calculated assuming the cells to be cylindrical.

Expt 2 compared the growth of $S$. marcescens on the roots of three grass species. Deschampsia flexuosa is characteristic of acid, infertile soils, whereas $\boldsymbol{H}$. lanatus and $\boldsymbol{L}$. perenne are potentially fast-growing species of fertile sites. Because of its known slow relative growth rate, $D$. flexuosa was planted out four weeks earlier than the others. with the aim of achieving similar-sized plants by the time of the harvest.

Expts 3 and 4 investigated the effect of nitrogen or phosphorus deficiency on the growth of bacteria on $L$. perenne roots. Two bacterial species, which had similar individual cell volumes, were inoculated either separately or in a mixture. The inoculum was about 500 cells ml-1 in monoculture or about 250 of each ml $^{-1}$ in mixture. The two species could easily be distinguished on the dilution plates because they are different colours, $S$. marcescens being red and the Flavobacterium sp. yellow. In Expt 3 some tubes received the 'complete' nutrient solution described above, others a 'low- $\mathrm{N}^{*}$ solution in which $\mathrm{KNO}_{3}$ and $\mathrm{Ca}\left(\mathrm{NO}_{3}\right)_{2}$ were reduced to $1 / 10$ of the concentration in the 'complete' solution, but $\mathrm{K}$ and $\mathrm{Ca}$ were kept unchanged by adding $\mathrm{KCl}$ and $\mathrm{CaCl}_{2}$. In Expt 4 some tubes received a 'low-P' solution, in which $\mathrm{NaH}_{2} \mathrm{PO}_{4}$ was $1 / 5$ of the concentration in the 'complete' solution. 
Table 2. Results of Expt 1, in which six bacterial species were grown on separate Lolium perenne plants

For further details see Table 1.

\begin{tabular}{|c|c|c|c|}
\hline Bacterium & $\begin{array}{c}\text { Numbers* } \\
\text { [millions (mg } \\
\left.\text { root dry wt) })^{-1}\right]\end{array}$ & $\begin{array}{c}\text { Mean volume } \\
\text { per cell } \\
\left(\mu \mathrm{m}^{3}\right)\end{array}$ & $\begin{array}{c}\text { Microbial } \\
\text { dry wt } \\
{\left[\mu \mathrm{g}(\mathrm{g} \text { root })^{-1}\right]}\end{array}$ \\
\hline Flavobacterium sp. A & $1 \cdot 53$ & 0.45 & 138 \\
\hline Serratia marcescens & $1 \cdot 46$ & 0.40 & 116 \\
\hline Flavobacterium sp. B & 0.96 & 0.64 & 122 \\
\hline Flavobacterium sp. C & 0.56 & 0.94 & 105 \\
\hline Flavobacterium sp. D & $0 \cdot 34$ & 0.86 & 59 \\
\hline Unknown & $0 \cdot 19$ & 1.56 & 59 \\
\hline
\end{tabular}

* At final harvest, $15 \mathrm{~d}$ after inoculation.

$\dagger$ Assumes bacteria have a dry wt/volume ratio of $0 \cdot 2$.

Table 3. Results of Expt 2, in which Serratia marcescens was inoculated on to three grass species, grown separately

Bacterial numbers are the means from harvests at 14 and $20 \mathrm{~d}$; relative growth rate of the plants was determined between those two harvests.

\begin{tabular}{|c|c|c|c|}
\hline \multirow[b]{2}{*}{ Host plant } & \multirow{2}{*}{$\begin{array}{l}\text { No. of } \\
S . \text { marcescens } \\
{[\text { millions (mg }} \\
\left.\text { root dry wt) }{ }^{-1}\right]\end{array}$} & \multicolumn{2}{|c|}{$\begin{array}{l}\text { Relative growth rate of plants } \\
\qquad\left(\mathrm{g} \mathrm{g}^{-1} \text { week }^{-1}\right)\end{array}$} \\
\hline & & $\begin{array}{c}\text { This } \\
\text { experiment }\end{array}$ & $\begin{array}{l}\text { Data of } \\
\text { Grime \& Hunt (1975) }\end{array}$ \\
\hline H. lanatus & $1 \cdot 10$ & 0.69 & $1 \cdot 56$ \\
\hline L. perenne & 0.83 & 0.56 & $1 \cdot 30$ \\
\hline D. flexuosa & $0 \cdot 50$ & $0 \cdot 18$ & $0 \cdot 81$ \\
\hline
\end{tabular}

\section{RESULTS}

\section{Expt 1. Growth of six bacterial species on Lolium perenne}

There were marked differences between the six bacterial species in numbers per $\mathrm{mg}$ root (Table 2). Similar differences occurred at the first harvest, and the overall difference between species was significant at $P<0.001$, by analysis of variance. The species with smaller cell volume tended to reach higher numbers (Table 2); the correlation coefficient between numbers and cell volume was -0.884 , significant at $P<0.02$. The estimate of microbial biomass per $g$ root was calculated from numbers $\times$ mean volume $\times$ (dry weight/volume). Since mean volume and numbers were approximately inversely related, the dry weight per $g$ root varies less than the numbers.

\section{Expt 2. Bacterial growth on three grass species}

There was no significant difference between harvests in number of bacteria per $\mathrm{mg}$ root, so Table 3 shows the mean of the two harvests. Although the mean differed more than twofold between host species the difference did not quite reach statistical significance $(P=0.07)$. Interpretation of the results is made more difficult because, in attempting to get plants of equal size by sowing $D$. flexuosa earlier, we overcompensated and the $D$. flexuosa plants were substantially larger than the others at harvest. Therefore no conclusion can be drawn about differences in bacterial growth between the host species, although it is worth noting that the mean bacterial numbers change in parallel with the plant relative growth rates, as measured between harvests in this experiment or in the more favourable growing conditions of Grime \& Hunt (1975). 


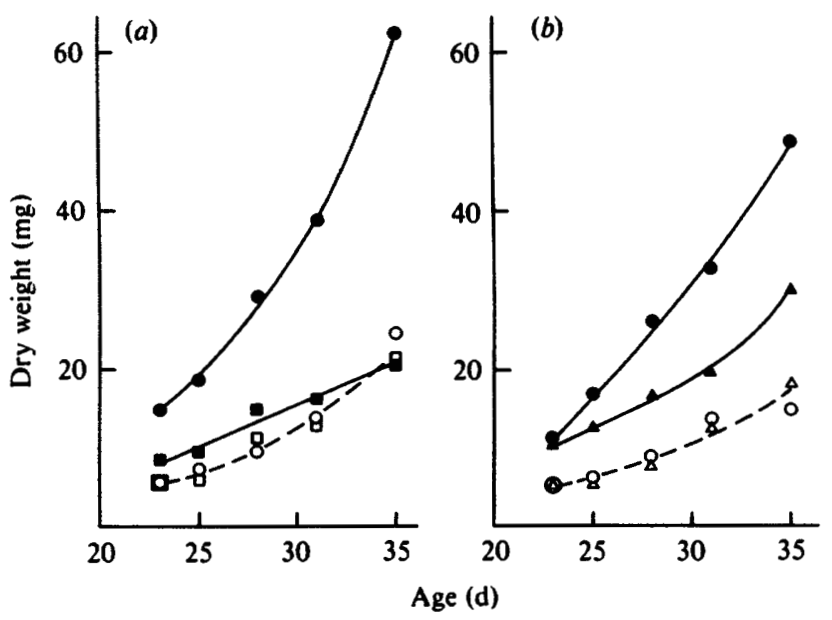

Fig. 1. Shoot and root dry weights of Lolium perenne plants. (a) Expt 3, (b) Expt 4. Black symbols, shoot weight; open symbols, root weight; $\bigcirc, O$, complete nutrients; $\square, \square$, low $N ; \Delta, \Delta$, low P. Data from the three bacterial treatments have been averaged; each point is thus the mean of nine plants. For statistical analysis of the results see Table 5 .

Table 4. Nitrogen and phosphorus concentrations in shoots of Lolium perenne plants at final hartest (Expts 3 and 4)

The results are averaged over all three bacterial treatments. For further details see Table 1.

\begin{tabular}{|c|c|c|c|c|}
\hline \multirow{2}{*}{$\begin{array}{l}\text { Nutrient solution } \\
\text { supplied to plants }\end{array}$} & \multicolumn{2}{|c|}{$\begin{array}{l}\text { Nitrogen concn } \\
\text { (\% of dry wt) }\end{array}$} & \multicolumn{2}{|c|}{$\begin{array}{l}\text { Phosphorus concn } \\
\text { (\% of dry wt) }\end{array}$} \\
\hline & Expt 3 & Expt 4 & Expt 3 & Expt 4 \\
\hline $\begin{array}{l}\text { Complete } \\
\text { Low-N }\end{array}$ & $\begin{array}{l}3.49 \\
1.67\end{array}$ & 3.53 & $\begin{array}{l}0.252 \\
0.240\end{array}$ & 0.357 \\
\hline Low-P & & 3.66 & & $0 \cdot 201$ \\
\hline Statistical significance* & $P<0.001$ & NS & NS & $P<0.001$ \\
\hline
\end{tabular}

- By analysis of variance; NS, not significant.

\section{Expts 3 and 4. Effect of decreased nitrogen and phosphorus supply}

In both these experiments shoot growth was reduced by nutrient deficiency but root growth was not significantly affected (Fig. 1, Table 5). The element whose concentration was reduced in the nutrient solution had a significantly lower percentage in the shoots at the final harvest (Table $4)$, but the concentration of the other element was unaffected.

Figure 2 shows the time-course of development of the bacterial populations in Expt 3. Since there was no significant effect of nitrogen concentration (Table 5), results from the two nutrient treatments have been averaged. When the bacterial species grew separately, $S$. marcescens reached maximum numbers by day 7 , whereas Flavobacterium sp. A increased more slowly and did not reach the same abundance as $S$. marcescens until the last harvest. The specific growth rate of $S$. marcescens between days 2 and 4 was $0.044 \mathrm{~h}^{-1}$ (but was presumably faster before day 2). The specific growth rate of Flavobacterium sp. A from days 4 to 7 was $0.080 \mathrm{~h}^{-1}$. In the mixture $S$. marcescens grew just as fast as in monoculture but Flavobacterium sp. A was even slower to colonize. The significance of these effects was confirmed by an analysis of variance on the data of harvests 3-5, which showed the between-species competition (i.e. monoculture v. mixture) and species $\times$ competition effects all to be significant at $P<0.001$. In Expt 4 (data not shown) there was a similar difference between the rates of colonization by the two species, and between one-species and two-species cultures. 


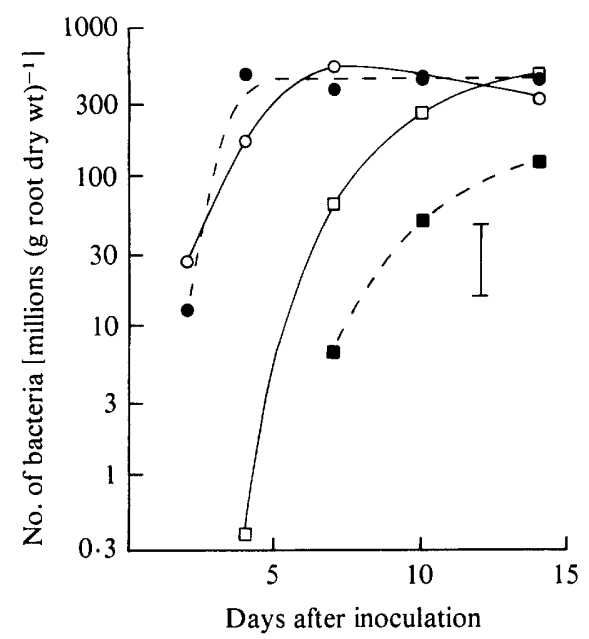

Fig. 2

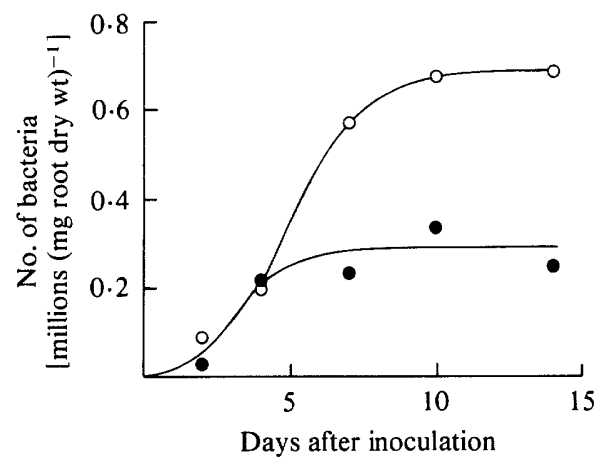

Fig. 3

Fig. 2. Numbers of bacteria per g dry weight of root in Expt 3. The mean of the two nutrient treatments is plotted on a $\log$ scale. $O$, Serratia marcescens; $\square, \mathbf{Q}$, Flavobacterium sp. A. Open symbols, bacteria on separate plants; black symbols, both bacterial species on same plant. The vertical bar represents the least significant difference $(P=0.05)$. Further statistical analysis is summarized in Table 5 .

Fig. 3. Numbers of Serratia marcescens per mg dry weight of root in Expt 4. treatment; $O$, low $P$ treatment. For statistical analysis see Tables 5 and 6.

Table 5. Results of analyses of variance on data from Expts 3 and 4

Numbers of bacteria per $\mathrm{mg}$ root were log-transformed before analysis, to make the variances more nearly equal. ${ }^{* * *}, P<0.001 ;{ }^{* *}, P<0.01 ;{ }^{*}, P<0.05 ;-$, not significant. For further details see Table 1 .

\begin{tabular}{|c|c|c|c|c|c|}
\hline \multicolumn{3}{|c|}{ Expt 3} & \multicolumn{3}{|c|}{ Expt 4} \\
\hline Root wt & Shoot wt & 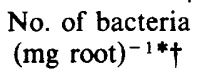 & Root wt & Shoot wt & $\begin{array}{l}\text { No. of bacteria } \\
(\mathrm{mg} \text { root })^{-1} \dagger\end{array}$ \\
\hline - & - & *** & - & - & $* * *$ \\
\hline - & $* * *$ & - & - & $* * *$ & - \\
\hline$* * *$ & $* * *$ & $* * *$ & $* * *$ & $* * *$ & $* * *$ \\
\hline * & - & - & - & - & - \\
\hline - & - & $* * *$ & - & - & $* * *$ \\
\hline- & $* * *$ & - & - & $*$ & $* *$ \\
\hline - & - & - & - & - & - \\
\hline
\end{tabular}

Bacterial species

Nutrient level

Time

Species $\times$ nutrients

Species $\times$ time

Nutrients $\times$ time

Species $\times$ nutrients $\times$ time
* Based on harvests 2-5 only, because of some 'zero' values at harvest 1 .

$\dagger$ In mixed-species plants, total number of bacteria per plant was used.

There was no consistent or significant effect of nitrogen supply on bacterial numbers (Table 6). In contrast, phosphorus supply did influence bacterial numbers. Figure 3 shows that $S$. marcescens initially grew at a similar rate in the two phosphorus treatments, but continued growth for longer in the low-P treatment and finally reached a higher plateau. Flavobacterium sp. $A$ and the mixed culture behaved similarly (Table 6). The significance of this effect is confirmed by analysis of variance on the results from all harvests, which shows a significant nutrients $x$ time interaction (Table 5), and by analysis on the last two harvests alone (Table 6). 
Table 6. Mean numbers of bacteria of last two harvests in Expts 3 and 4

The results are shown as millions of bacteria (mg root) $)^{-1}$. For further details see Table 1.

\begin{tabular}{|c|c|c|c|c|}
\hline & \multicolumn{2}{|c|}{ Expt 3} & \multicolumn{2}{|c|}{ Expt 4} \\
\hline & Complete & Low-N & Complete & Low-P \\
\hline $\begin{array}{l}\text { S. marcescens } \\
\text { Flavobacterium sp. A } \\
\text { Mixture } \\
\text { Mean }\end{array}$ & $\begin{array}{l}0.30 \\
0.42 \\
0.53 \\
0.42\end{array}$ & $\begin{array}{l}0.50 \\
0.30 \\
0.55 \\
0.45\end{array}$ & $\begin{array}{l}0.26 \\
0.43 \\
0.42 \\
0.37\end{array}$ & $\begin{array}{l}0.62 \\
0.72 \\
0.63 \\
0.66\end{array}$ \\
\hline Statistical significance* & \multicolumn{2}{|c|}{ Not significant } & \multicolumn{2}{|c|}{$P<0.02$} \\
\hline
\end{tabular}

- Significance of difference between complete-nutrient and low-nutrient treatment, by analysis of variance.

\section{DISCUSSION}

The aim of these experiments was to study bacterial growth in a simplified system, and inevitably the conditions were artificial in various ways. One of these is that the plants at first grew axenically; during this time the roots presumably produced organic substances, which were not used by micro-organisms. Then the bacteria were inoculated into a small volume of sand. The time-courses in Figs 2 and 3 were probably strongly influenced by the rate of spread of the bacteria, through a rhizosphere initially relatively rich in substrate; thus they would bear little resemblance to the time-course of colonization of roots in soil. Nevertheless, the results do provide useful information on rates of spread which can occur. The motile $S$. marcescens achieved near plateau levels within $7 \mathrm{~d}$, and the non-motile Flavobacterium sp. A in about $10 \mathrm{~d}$ (Fig. 2). If we assume that the bacteria had by this time reached all parts of the root system, this indicates that the non-motile Flavobacterium sp. A can spread about $7 \mathrm{~cm}$ (the depth of the sand) in $10 \mathrm{~d}$, even without the help of downward percolating water. There is, of course, no proof that the faster initial growth by $S$. marcescens was due to its motility, although this is likely to have contributed. Serratia marcescens is a facultative anaerobe, whereas Flavobacterium sp. A is a strict aerobe; although the sand growth medium contained air there might have been local anaerobic pockets near the root in which $S$. marcescens would be favoured.

The bacterial numbers in Expt 1, presented in Table 2, were measured $15 \mathrm{~d}$ after inoculation and so probably represent plateau numbers per $\mathrm{mg}$ root. Although numbers per $\mathrm{mg}$ root varied eightfold between species (Table 2), estimated biomass varied only twofold, suggesting that all the bacteria were limited by organic substrate supply rather than some specific growth factor. Since no rigorous statistical test can be applied to the biomass values it is uncertain whether Flavobacterium sp. D and the unknown species genuinely had lower values: tests on ability to use various substrates failed to indicate any reason for slower growth of these two species. According to the model of Newman \& Watson (1977), if exudation rate remains constant, bacterial numbers on the root surface should continue to increase for at least $40 \mathrm{~d}$. If the plateau seen in Figs 2 and 3 indicates that on older roots bacterial populations were approximately static, this suggests that the supply of substrate had declined to a level only sufficient to satisfy the maintenance requirements of the bacteria. It is not known whether the bacteria were using mainly soluble organic exudates as substrate or insoluble materials as well. The fact that none of the six species could degrade either cellulose or pectin, major components of mucigel (Oades, 1978), suggests that they were not using the root mucigel layer, in which they were presumably embedded, as a substrate.

Serratia marcescens, initially isolated from $L$. perenne rhizosphere, also grew well on two other grasses (Table 3). Although there was no significant difference in bacterial numbers between the three host species, the possibility that slow-growing species such as $D$. flexuosa, which are tolerant of infertile sites, exude less organic material and hence support a smaller rhizosphere population, would be worth further investigation.

In Expt 3 Flavobacterium sp. A had on day 7 only about $1 / 10$ as many cells per $g$ root in the mixed culture as in the monoculture (Fig. 2). Even allowing for the initial inoculum containing 
only half as many cells in the mixture, it is clear that early multiplication of Flavobacterium sp. A was retarded by the presence of $S$. marcescens. This was confirmed in Expt 4 (data not shown). However, Flavobacterium sp. A continued to increase in abundance in the mixture after $S$. marcescens reached its plateau level. Thus Flavobacterium sp. A, although slower to multiply initially, is evidently an effective competitor. It would be interesting to know the outcome if the experiments had been continued longer: would the two bacterial species reach a balance or would one be eliminated? Bennett \& Lynch (1981) inoculated axenic wheat, barley and maize with three species of bacteria, separately or in mixtures. The rhizosphere populations reached plateau levels (per g root) after 2-4 d. Usually the bacterial species continued to coexist after that, although one species was eliminated in one experiment. The more rapid attainment of plateau populations than in our experiments was probably due to the different inoculation method: the whole sand volume was flooded with the bacterial suspension, so scarcely any migration of bacteria would be necessary.

In Expts 3 and 4 the deficiency of nitrogen or phosphorus was sufficient to cause a marked reduction of shoot growth, though not of root growth (Fig. 1). It is thus perhaps surprising that the low-N treatment had no significant effect on the bacterial populations, and the low-P treatment caused a marked increase (Table 6). Since the root weights were unchanged, the treatments influenced numbers of bacteria per plant in the same way as numbers per $\mathrm{g}$ root. In another experiment (Turner \& Newman, 1984) L. perenne grown in the same way was inoculated with a fungus, Rhizoctonia sp. Fungal abundance on the root surface was unaffected by a low-N treatment but approximately doubled in low-P, closely paralleling the results in Table 6 . These results suggest that nitrogen and phosphorus were not directly limiting to microbial growth, but that phosphorus-deficient plants provided more organic substrate for rhizosphere microorganisms. Unfortunately there is no direct information available on how nutrient deficiency influences exudation by $L$. perenne. Bowen (1969) found that loss of amino acids from roots of Pinus radiata seedlings was reduced by nitrogen deficiency but increased by phosphorus deficiency. In contrast, Rovira \& Ridge (1973) found that loss of soluble ${ }^{14} \mathrm{C}$-labelled compounds from roots of young wheat plants was reduced by phosphorus deficiency. Ratnayake et al. (1978) and Graham et al. (1981) reported that exudation of sugars and amino acids from sudangrass and orange was increased by phosphorus deficiency; however, the roots were not axenic and may have been physically damaged. Increased sugar exudation was not accompanied by increased sugar content within the root, but there was decreased phospholipid content, suggesting that phosphorus deficiency may make roots more 'leaky'. This subject deserves further investigation.

We thank Dr R. Campbell for much advice and encouragement. This research was supported by a grant from the Natural Environment Research Council.

\section{REFERENCES}

ARNON, D. I. (1938). Microelements in culture solution experiments with higher plants. American Journal of Botany 25, 322-328.

BENNETT, R. A. \& LYNCH, J. M. (1981). Bacterial growth and development in the rhizosphere of gnotobiotic cereal plants. Journal of General Microbiology 125, 95-102.

BOWEN, G. D. (1969). Nutrient status effects on loss of amides and amino acids from pine roots. Plant and Soil 30, 139-142.

Graham, J. H., Leonard, R. T. \& Menge, J. A. (1981). Membrane-mediated decrease in root exudation responsible for phosphorus inhibition of vesicular-arbuscular mycorrhiza formation. Plant Physiology 68, 548-552.
Grime, J. P. \& HUNT, R. (1975). Relative growth rate: its range and adaptive significance in a local flora. Journal of Ecology 63, 393-422.

HewITT, E. J. (1966). Sand and Water Culture Methods Used in the Study of Plant Nutrition, 2nd Edn. Farnham Royal: Commonwealth Agricultural Bureaux.

Newman, E. I. \& Watson, A. (1977). Microbial abundance in the rhizosphere: a computer model. Plant and Soil 48, 17-56.

OADES, J. M. (1978). Mucilages at the root surface. Journal of Soil Science 29, 1-16.

RatNayake, M., Leonard, R. T. \& Menge, J. A. (1978). Root exudation in relation to supply of phosphorus and its possible relevance to mycorrhizal formation. New Phytologist 81, 543-552. 
Rovira, A. D. \& RIDGE, E. H. (1973). Exudation of ${ }^{1+C}$-labelled compounds from wheat roots: influence of nutrients, micro-organisms and added organic compounds. New Phytologist 72, 1081-1087.
TURNer, S. M. \& Newman, E. I. (1984). Fungal abundance on Lolium perenne roots: the influence of nitrogen and phosphorus. Transactions of the British Mycological Society (in the Press). 